\section{Psoas Abscess Accompanied by Neonatal \\ Appendicitis: A Case Report}

\author{
Neonatal Apandisite Eşlik Eden Psoas Apsesi: \\ Olgu Sunumu
}

\author{
Mehmet Yücel $\odot$ \\ Fatma Hilal Yılmaz $\odot$ \\ Nuriye Tarakçı $\odot$ \\ Nazlı Dilay Gültekin $\odot$ \\ Hüseyin Altunhan $\odot$ \\ Hacı Hasan Esen 10
}

\begin{abstract}
Neonatal appendicitis is a very rare event leading to acute abdomen manifestation in neonatal period, and is associated with high mortality rates. In these patients, symptoms and findings are not apparent, most of the time, urgent surgery is carried out without preoperative diagnosis; and diagnoses are made with intraoperative findings or pathological results. In the present case, a case with neonatal appendicitis that had psoas abscess with swelling and circulatory disorder in the right leg on the $15^{\text {th }}$ day of life is presented.

Keywords: Neonatal appendicitis, newborn, psoas abscess

öz

Neonatal apandisit yenidoğan döneminde akut batın tablosuna yol açan çok nadir bir neden olup, yüksek mortalite oranıyla birliktedir. Belirti ve bulguların silik olduğu bu tabloda çoğu defa preoperatif tanı konulamadan acil cerrahiye gidilmekte, intraoperatif ya da patoloji sonucuyla karara varılmaktadır. Bu olguda, yaşamının 15. gününde sağ bacakta şişlik ve dolaşım bozukluğu ile prezente olan psoas apsesinin eşlik ettiği bir neonatal apendisit olgusu paylaşılmıştır.
\end{abstract}

Anahtar kelimeler: Neonatal apandisit, yenidoğan, psoas apsesi
Alındığı tarih: 07.02.2019

Kabul tarihi: 22.03.2019 Online Yayın tarihi: 06.12.2019

Mehmet Yücel Necmettin Erbakan Üniversitesi Meram Tıp Fakültesi Neonatoloji Bölümü, Konya - Türkiye mehmeyucel@gmail.com ORCiD: 0000-0001-9975-8361

F.H. Yilmaz 0000-0002-1152-9773

N. Tarakçı 0000-0003-2444-4725 N.D. Gültekin 0000-0002-9624-1954

H. Altunhan 0000-0003-0264-8671 Necmettin Erbakan Üniversitesi, Meram Tıp Fakültesi, Neonatoloji Bilim Dalı, Konya, Türkiye

H.H. Esen 0000-0002-8559-2476 Necmettin Erbakan Üniversitesi, Meram Tıp Fakültesi, Patoloji Bilim Dalı, Konya, Türkiye

\section{INTRODUCTION}

Appendicitis, which is rarely seen during neonatal period, is an acute abdominal emergency, which might be diagnosed based on intraoperative, pathology or autopsy findings, progressing with severe clinical manifestation, and operated without preoperative diagnosis. A total of 141 cases with neonatal appendicitis have been reported so far. This entity was firstly defined by Deiss in 1908 and 8 cases were from our country ${ }^{(1,2)}$. Mortality rates are high due to the delays in the diagnosis, and the complications associated with the surgery in cases with neonatal appendicitis in which the symptoms and symptoms are not apparent. In recent years, it has been observed that this rate has decreased to $18 \%$ from $28 \%$ with the differences in the treatment approaches $(2,3)$. In this case study, patient with neonatal appendicitis that had psoas abscess presenting with swelling and circulatory disorder in the right leg on the $15^{\text {th }}$ day of life was presented.

\section{CASE}

The 4500-gr female baby that was born from a 40 -year-old mother in her $38^{\text {th }}$ gestational week in her $3^{\text {rd }}$ pregnancy with caesarian section was hospitalized in the neonatal service with swelling and

(2) Telif hakkı Izmir Dr. Behçet Uz Cocuk Hastalıkları ve Cerrahisi Eğitim ve Araștrma Hastanesi'ne aittir. Logos Tıp Yayıncılık tarafindan yayınlanmaktadır.

Bu dergide yayınlanan bütün makaleler Creative Commons Atff-GayriTicari 4.0 Uluslararası Lisansı ile lisanslanmıștır.

Licenced by Creative Commons Attribution-NonCommercial 4.0 International (CC BY-NC 4.0) 
purple skin mark on her right leg on the postnatal $15^{\text {th }}$ day of life. In her physical examination, other system examinations of the patient were normal, and there was swelling and redness on her right thigh, and an increase of $3 \mathrm{~cm}$ in diameter and cyanosis in the inner part of the right thigh, the movements of the hip were painful and limited. Laboratory tests of the patient, whose vital signs were within normal limits, revealed higher WBC counts (21.600/ $\mathrm{mm}^{3}$ ) and C-reactive protein level ( $\left.85 \mathrm{mg} / \mathrm{L}\right)$. Bilateral lower extremity venous color Doppler ultrasonographic examination results were unremarkable. Two cystic lesions were detected in the abdominal Ultrasonography (USG). In the pelvic Magnetic Resonance Imaging (MRI), there was a lesion with septate measuring approximately $4 \times 2.5 \mathrm{~cm}$ in the right lower quadrant (Figure 1A). The patient was diagnosed with intra-abdominal abscess and double

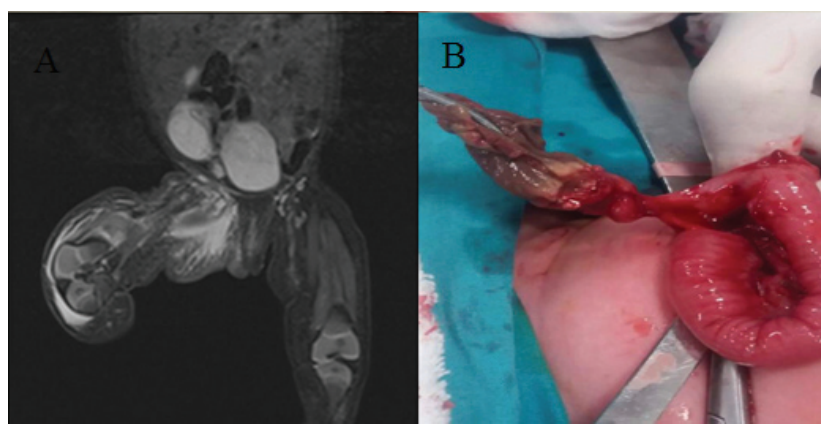

Resim 1.

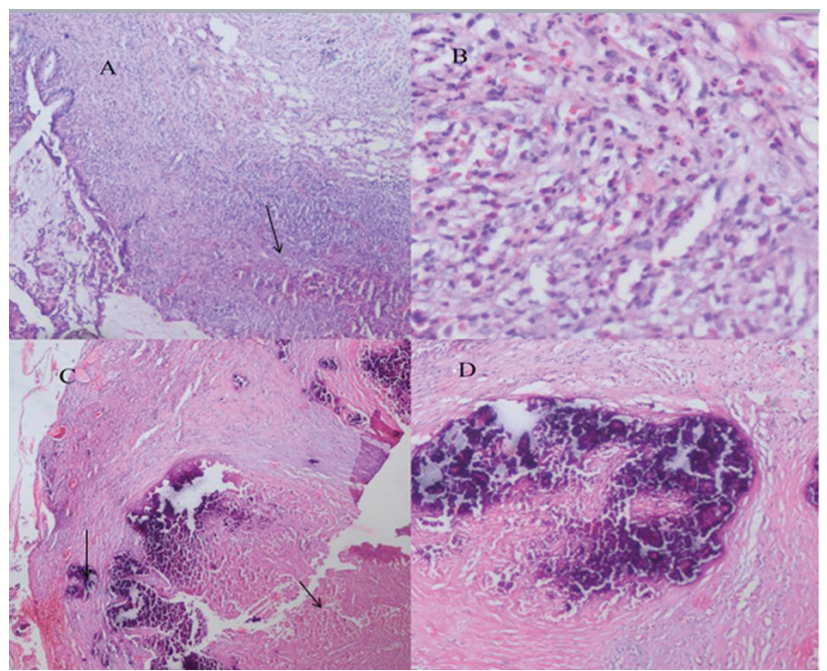

Resim 2. antibiotics were initiated for her. On the fourth day of the treatment, no clinical responses were seen, and in the laparotomy that was carried out for diagnostic purposes by the pediatric surgery, a dirty white moderately hard cystic lesion measuring $5 \times 2 \times 0.5 \mathrm{~cm}$ with a brown-colored wall on one side in the terminal ileum was detected. The adherent appendix was excised together adjacent part of the terminal ileum, and the neighboring psoas abscess was drained (Şekil 1B). In the histopathological examination of the excised material, collagenase tissues with necrosis and calcific degeneration involving a large part of the appendix tissue, and patchy areas of mixed inflammatory cell infiltration were detected (Figures 2A,B,C,D). Following the second day of operation, the symptoms of the patient regressed, and she was discharged with recovery.

\section{DISCUSSION}

The cecal swelling, which emerges as a conical extension of the caudal part of the primitive intestine ring, is a tubular body that starts in the junction of the cecum tania in the right lower quadrant when the embryo is $12 \mathrm{~mm}$ in length, which eventually forms the appendix. In $95 \%$ of the cases, the appendix is located intraperitoneally, namely, behind the cecum in $65 \%$, and at the pelvis in $30 \%$ of the cases, while in $5 \%$ of the cases, it is located in the retrocolic and retro-cecal area ${ }^{(4)}$.

The much lower incidence of appendicitis in the neonatal period is explained with anatomically shortlength appendix with a wide orifice being attached to the cecum with a funnel-like attachment, and the low possibility of intraluminal obstruction thanks to functional liquid diet used during neonatal period ${ }^{(5)}$. Since the symptoms and signs of appendicitis are not specific in the neonatal period, the diagnosis is delayed; and for this reason, the incidence of perforation enhances due to significantly increased number of anatomic and physiological factors when compared to other pediatric age groups. In anatomical and physiological terms, perforation and sepsis are seen frequently because of inadequate omentum volume, thinner appendix wall in the newborn, small size of 
peritoneal cavity and the insufficiency of the defense mechanisms that would ensure the perforation to remain localized. The presence of perforation is the most important determinant of prognosis ${ }^{(1,2)}$. Increased perforation, faster progression towards peritonitis and following septic shock are associated with higher morbidity and mortality rates compared to other age groups. In our case, there was perforated appendicitis that limited itself together with psoas abscess; however, there were no clinically serious disease symptoms. In a retrospective singlecentered study conducted in our country, 2 cases were seen, and in another study conducted on the frequency and etiology of perforated neonatal appendicitis, perforation was reported in $5 \%$ of the cases with neonatal appendicitis ${ }^{(6)}$.

Necrotizing Enterocolitis (NEC), Hirschsprung's Disease (HD), Cystic Fibrosis (CF), meconium plug, inguinal hernia, umbilical hernia, gastroenteritis, Group B Streptococcal septicemia and chorioamnionitis are defined as the risk factors for neonatal appendicitis. It is considered that the obstruction depending on the meconium ileus on the basis of cystic fibrosis has an etiological role in the pathogenesis of appendix ${ }^{(7)}$. However, Karaman et al. ${ }^{(2)}$ conducted a study in which they examined 128 cases with NA, and reported only one case with CF. Increased levels of immunoreactive trypsinogen were detected during CF screening program; however, samples of sweat were not collected because the patient was in the neonatal period, and the patient was followed-up for CF. Abdominal distension, vomiting, abdominal tenderness, restlessness or drowsiness and increased body temperature were the most common symptoms indicated in the reports published previously ${ }^{(8)}$. Symptoms and findings are similar to those of neonatal sepsis caused by other abdominal diseases. Since they are not specific, they may not give any clues for clinical diagnosis ${ }^{(2)}$. There were vomiting without bile, abdominal distension and right inguinal swelling in our patient. In abdominal radiography, pneumoperitoneum, free peritoneal fluid, thickened abdominal wall, and obliteration in the psoas margin may be seen. The primary diagnostic imaging methods in childhood for appendicitis are US and computed tomography. Although ultrasound has several limitations, it was shown that it was more effective than plain radiographies in showing intra-abdominal fluid, intestinal wall thickness and intestinal perfusion. The detection rate of appendicitis by US ranges from $22 \%$ to $98 \%$ because it is a user-dependent method ${ }^{(9)}$. There were no specific findings in the plain radiograms of our case. A cystic abdominal mass extending towards appendiceal lodge was detected in the abdominal US and pelvic MRI; however, appendicitis could not be diagnosed. The reason for preferring MRI instead of abdominal CT was to avoid the high radiation exposure that would occur in CT. Our patient could be diagnosed with the pathology result of the excision material after the operation.

The incidence of perforation is $85 \%$ in neonatal appendicitis; and the average time to diagnosis of perforated cases is $3.3 \pm 3$ days after the onset of complaints. Our case was diagnosed on the $4^{\text {th }}$ day after the postnatal $15^{\text {th }}$ day when her complaints started. Appendiceal abscess or mass was described in 9 cases so far. Our patient is differentiated from other cases in the literature with atypical clinical presentation with swelling and circulatory disorder in the right leg.

Our patient did not present with severe clinical presentation, but with psoas abscess for the first time. A rapid decision-making process and a correct management jointly performed with surgery in cases with neonatal appendicitis significantly reduce mortality rates.

Conflict of Interest: There is no conflict of interest between the authors.

Informed Consent: Written informed consent was not obtained from the patients because the study was performed retrospectively.

Çıkar Çatışması: Yazarlar arasında çıkar çatışması bulunmamaktadır.

Hasta Onamı: Çalışmanın retrospektif olarak gerçekleştirilmesi nedeniyle hastalardan yazılı onam alınmamıştır. 


\section{REFERENCES}

1. Raveenthiran V. Neonatal Appendicitis (Part 1): A Review of 52 caseswithAbdominalManifestation. J NeonatalSurg. 2015;4(1):4.

2. Karaman A, Cavuşoğlu YH, Karaman I, Cakmak O. Seven cases of neonatalappendicitiswith a review of the English languageliterature of thelastcentury. Pediatr Surglnt. 2003;19(11):707-9.

https://doi.org/10.1007/s00383-003-1030-5

3. Arias-Llorente RP, Flórez-Díez P, Oviedo-Gutiérrez M, SuárezRodríguez $\mathrm{M}$, Costa-Romero $\mathrm{M}$, et al. Acute neonatal appendicitis: a diagnosis to consider in abdominal sepsis. J Neonatal Perinatal Med. 2014;7(3):241-6.

4. Sadler TW. Langman's Medikal Embryology. 6. ed., Philadelphia: Williams and Wilkins; 2006.

5. Arora NK, Deorari AK, Bhatnagar V, Mitra DK, Singhal PK et al. Neonatal appendicitis: A rarecause of surgicalemergency in pretermbabies. Indian Pediatr 1991;28:1330-3.

6. Saraç M, Bakal Ü, Aydın M, Tartar T, Orman A, Kazez A, et al. Neonatal gastrointestinal perforations: the 10-year experience of a reference hospital. Indian J Surg. 2017;79(5):431436. https://doi.org/10.1007/s12262-016-1565-z

7. Managoli S, Chaturvedi P, Vilhekar KY, Gupta D, Ghosh S. Perforated acut eappendicitis in a term neonate. Indian J Pediatr. 2004;71(4):357-8. Review. https://doi.org/10.1007/BF02724108

8. Stifle D, Stallmach T, Sachet P. Acute appendicitis in neonates: complication or morguessuitgeneris? Pediatr SurgInt. 1998;14:122-123. https://doi.org/10.1007/s003830050457

9. Khan RA, Menon P, Rao KL. Beware of neonatal appendicitis. J Indian Assoc Pediatr Surg. 2010;15(2):67-9. https://doi.org/10.4103/0971-9261.70646 